\title{
Historical and Literatural Value of Hoang Dinh Ai's Theological Epitaph in Vietnam
}

\author{
Zong Yu Luo, Nguyen Van Hai \\ College of Chinese Language and Literature, Hunan University, Changsha, China \\ Email address: \\ Vanminh.hai2009@gmail.com (Nguyen Van Hai) \\ To cite this article: \\ Zong Yu Luo, Nguyen Van Hai. Historical and Literatural Value of Hoang Dinh Ai's Theological Epitaph in Vietnam. International Journal \\ of Literature and Arts. Vol. 6, No. 1, 2018, pp. 1-6. doi: 10.11648/j.ijla.20180601.11
}

Received: October 17, 2017; Accepted: November 10, 2017; Published: January 10, 2018

\begin{abstract}
The article raises the orgin of the holy epitaph which is the foundation searching for relevant materials to check evidence and compare the accuracy of the documents. Through the content of the epitaphs, the author presents some of comments on the structural form of the text, the method of using literature dispostion on the epitaph; together with clarifying the conflict between the composer and the history written by the Imperial court, also the discrepancy in dates recorded in the name and tile of the epitaph. Additionally, the writing details the documentary values on literature and historical research, especially studying the family background, the marriage and lifetime merits of Thái Tể (Glorious Grand Duke) Hoang Dinh $\mathrm{Ai}$, a meritorious official under the reign of Le Trung Hung with historic events relating to the conflict between Le Dynasty and Mac Dynasty in the $16^{\text {th }}$ century in Vietnam. All the contents of the epitaph is introduced at the end of the text.
\end{abstract}

Keywords: Epitaph, Theology, Glorious Grand Duke, Hoang Dinh Ai, Writer, Name of a Reign's Years

\section{Introduction}

For a long time, when exploring the biography and lifetime merits of Thai te Glorious Grand Duke Hoang Dinh Ai, an meritorious official under the reign of Le Trung Hung, scholars nomarly based on historical materials in collections of Vietnamese history written by the Imperial court such as "Complete Annals of Dai Viet", "Regulations of Dynasties in Classification", "Khâm định Việt sủ tông giám cuong muc". Nevertheless, those are limited to writings in general and summary. There are some points like his family background, marriage, particular merits in the period of quelling Mac Dynasty also the duty assigned after the restoration of Le Dynasty which have not been clear yet. Today, on the Hoang Dinh family annals (1) we discover the copy of the contents of the epitaph "Than Dao Minh Bi" recording his biography and merits. I regret to inform that the material epitaph has been lost (2) in order to have the base to check evidence on the accuracy of the document, we conducted a investigation on relevant materials and then discovered that the epitaph was also transcribed literally in three sets of books which are currently being preserved at the library of the Institute of Han-Nom Studies - Hanoi: "Vinh Loc district monograph" Author District Chief Luu Cong Dao edited in the $15^{\text {th }}$ year of Gia Long (1816) "Vinh Loc climatic monograph" edited in the year 14th of Tu Duc (1867) and "Thanh Hoa province Vinh Loc district monograph" edited in the fourth year of Duy Tan (1911) (3). The comparison of various transcripts shows an indifference, just some information still has been in conflict with those written by the Imperial court such as the author and the date. As a result, we generally comprehend every single areas and then introduce the whole contents of the epitaph.

\section{Content of the Theological Epitaph}

\subsection{Overview of the Theological Epitaph}

\subsubsection{About the Documentary Structure}

The epitaph was written by using the traditional method. It means the former is "Ki" and the latter is "Minh". The "Ki" uses the genre of prose interlacing the style using couplets, while "Minh" is composed in the four-syllable emotional verse. The text is clearly and connectedly laid-out, the writing is simply abridged, the use of the classic reference is standard, exact and soulful. It proves that the composer possesses universal knowledge and his level of confucianism is passionately deep. 


\subsubsection{About the Author of the Epitaph}

The historical materials written by Imperial court uniformly are recorded that "In the eighth year of Hoang Dinh (1607), Hoang Dinh Ai passed away, to live to be eighty-one. He was highly educated, grasped the art of warfare and command troops in a serious and strict manner. Helping to scheme internally, following to conquer externally, by himself experiencing hundreds of battles, coming and getting, being both the civil and military mandarin, \{behaving towards people\} not discriminating on the basis of order and authority, treating feudal intellectuals very well, maintaining a good manner. Everybody praised him for his outstandingness. The court awarded LiteratureAffair Collective Declamation, Nhã - độ - Mậu -Nghĩa công, granted the posthumous name "Hau Duc", burried at Van La hamlet, Thach Thanh district, required the people of 10 villages làm tạo lệ, the King ordered Left Vice Minister of Rites Nguyen Le composed the epitaph to record his merits" (4).

According to the history written by Imperial court, clearly the writer of the epitaph is Nguyen Le but four documents we have studied reveal the fact that the composer is PhD Ngo Tri Hoa. The contents of name and date have in common \{Fourth Water-Dragon competition-examination, Doctor comes from, Academic Vice-official, Dong Cac Great Academician, Dong Thanh, Ly Trai, Ngo Tri Hoa compiles\} (it means Ngo Tri Hoa born in Ly Trai village, Dong Thanh district, passing the Water Dragon-year doctoral examination (1952), being an academic vice-official, Dong Cac Great Academician, writes). Thus, probably after Hoang Dinh Ai passed away, two epitaphs for him could be erected? This point could hardly happen because the theological epitaph has the origin from China and it is one of genres of tombstone; with the main purpose of singing the praise of merits and professional ethics of the dead. Looking upon the official-organisation regulation of Duong Dynasty, offcials with the fifth level or above are allowed to set the theological epitaph while in the reign of Minh Dynasty, so do the ones with the third level or above (5). Moreover, Chinese classic geomancers assume that the south-east of the grave is the spirituality, the setting of the epitaph upon the spirituality is called theological gravestone (6).

In the history of both China and Vietnam, we have not found any personality that after dead, is set in two theological epitaphs. Rarely, there are some individuals who have both the tombstone and the theological epitaph. Also according to the name and tile of the epitaph, from the native village to the competition-examnination and social status agree that Ngo Tri Hoa born in Ly Trai village, Dong Thanh district, passing the WaterDragon-year doctoral examination, the $12^{\text {th }}$ Quang Hung reign's year (1592). In this examination, Ngo Tri Tri, who is the father of Ngo Tri Hoa, also qualified as $\mathrm{PhD}$ and it is the only case in the Vietnamese history that both father and son qualify in the same competition-examination. Furthermore, reading the contents of the narrative part of the epitaph, we realise that the composer deeply studied the family of Hoang Dinh Ai, hence, concretely recorded from the great grandparent Great Hien to childrens and chilrens-inlaw. It is sensible when getting the position of Surveillance Commissioner in Thanh Hoa, Ngo Tri Hoa had a chance to examining and discovering the influential family and marriage of Hoang Dinh Ai who originally is the mothersiderelative of Trinh Lords.

\subsubsection{About the Matter of Dates Written on the Epitaph}

The historical materials written by Imperial court uniformly recorded that Hoang Dinh $\mathrm{Ai}$ died on $15^{\text {th }}$ December the eighth Hoang Dinh reign's year (1607) living to be eighty-one. The same information is also found in the contents of the epitaph, moreover, the cause of his death is clearly written that he caught a cold and then died at Kinh $\mathrm{Su}$. It is unsure of the reason why in the name-and-tile part of the epitaph, it was written March, the seventh Hoang Dinh reign's year (1606). Thus, the comparison between the contents of the epitaph and historical materials about his death date demonstrates a conflict. Specifically, the name and tile was recorded that in the seventh Hoang Dinh reign's year (1606), the epitaph was established but in that year, he still was alive. It is unreasonable to happen. We assume that the transcriber probably made a mistake in writing the year. The precise information must be March, the ninth Hoang Dinh reign's year (1609), the epitaph was built; that is, at that moment, he had died for more than three months, and had been taken from Kinh Su to Van Lung hamlet, Thach Thanh district to hold the funeral before the establishment of the epitaph. Could it be more reasonable?

\subsubsection{About the Matter of Family Influence and Marriage}

The contents of the epitaph clearly provide us the details of his origin which hisorical materials seldom touched upon. He was originally from Bien Thuong village, Vinh Phuc (7) district. His grandfather was awarded "Privilege Gold sealpurplebelt Glorious-wealthy Great Mandarin", Grand Nurture rank, Prosperous Grand Duke title. His grandmother was awarded the Lady. His father was awarded "Privilege Goldseal-purplebelt Glorious-wealthy Great Mandarin", Grand Upbringrank, Grave Duke title. His mother was granted the Lady. The family historically belongs to a descent of the cultivation of hapiness and kindness; that means to accumulate the virtuous for the hapiness of latter generations. His name at birth was Dinh Thai (8) (another was Cuong Bao), holding Organisation-Strategy Meritorious Official, Lieutenant Colonel, Gentle Duke title. His son is Phuc, holding Tan Tri Meritorious Official, Đặc tiến Phụ quốc Thượng tướng quân Điện tiền, Commander-General of the East Army, Right Commander-in-chief, Upright Duke title, His daughter married Hiep Muu Prestigous Meritorious Official, Commander-General of the South Army, Judgement Commander-in-chief, Duke title. His descendants is numerous, family relatives become increasingly luxuriant, and merits stand out in relief; futhermore, inherited a fortune of authority and possession, the sense of purpose is unshakeable. All of those advantages are owing to the great blessing that he left. 


\subsubsection{About the Spiritual Lifetime}

The epitaph recorded in a very detailed way about his lifetime merits. Just at the start of the text: The preaching affinity part, the writer used the classic reference "Thieu Khang (9) had the merit of devoting himself to follow and aid, rehabilitate the dogma of Ha Dynasty. La Cong (10) assisted Tuyen Vuong (11) in the time when Tu Di invader (12) encroached upon, also restored the constant obligations of morality of $\mathrm{Ha}$ Dynasty" as a foundation to reason, compare, lead the matter into the narrative contents. The narrative part specifies his office and title granted: suy trung dực vận, Hiệp mưu Đồng đức, Kiệt tiết Tuyên lực công thần, Đặc tiến Khai phủ, Goldseal-purplebelt Glorious-wealthy Great Mandarin, Literature-Affair Collective Declamation, Court-Affair Participation, Chancellor with Glorious Great Duke title; following by records of his merits from Thuan Binh reign's years (1548-1556) when he responded to the appeal of Clairvoyant-peaceful Great Royal Prince Trinh Kiem to his death, in the eighth Hoang Dinh reign's year (1607). The method of writing is to record, list his merits annually; sometimes, bravo, comment on the personality's talent and virtue; transmiss the inspiration, which make readers imagine that they was experiencing the contemporarily real scene. The ending of the narrative part is exclaimative words interlacing with good praises of his merits, which put him into the position worthy as a meritorious official subject in the time of $\mathrm{Ha}$ and $\mathrm{Chu}$ Dynasties that the preaching-affinity section has touched upon.

\subsection{The content of Stele with Minh on the Theological Epitaph}

Always hear: Goodness opens restoration, thus the era surely creates heroes who assist. Hence, loyal subjects like Thieu Khang (13) devoted himself to follow and aid on the rough and obstacle path, restored the prosperity of the political dogma of Ha Dynasty. La Cong (14) assisted Tuyen Vuong (15) in the time when Tu Di (16) invader encroached upon, also restored the constant obligations of morality of $\mathrm{Ha}$ Dynasty. Throughout the ages afterward, how there are not any virtue, to be like that, is this right? thus, then is to leave the world a good fame!

As an official assisting Vietnamese Kings, he is awarded: Suy trung Dực vận, Hiệp mưu Đồng đức, Kiệt tiết Tuyên lực công thần, Đặc tiến Khai phủ, Goldseal-purplebelt Gloriouswealthy Great Mandarin, Literature-Affair Collective Declamation, Court-Affair Participation, Chancellor with Glorious Great Duke title; additional rewards: Bình chương Nhã khánh - Mậu Nghĩa công, given the posthumous name of Hau Duc. His family name is Hoang, his first name is Dinh $\mathrm{Ai}$; his origin is Bien Thuong, Vinh Phuc district. His grandfather is indebting granted: Privilege Goldsealpurplebelt Glorious-wealthy Great Mandarin, GrandNurture, Prosperous Grand Duke title. His grandmother was awarded the Lady. His father was awarded Privilege Goldsealpurplebelt Glorious-wealthy Great Mandarin, Grand Upbring rank, Grave Duke title. His mother was granted the Lady.
The family historically belongs to a descent of the cultivation of hapiness and kindness; that means to accumulate the virtuous for the hapiness of latter generations. His excellency was born at the hour of Tiger $23^{\text {th }}$ December the year of FirePig, the fifth Thong Nguyen reign's year (1527) (17) was spiritually crystallised by heaven and earth, free willing, inherited the ancestor's benevolence and righteousness. He had the talent for war strategy as La Thai Cong (La Vong), also got a refined-mannered carriage and was good at prose and verse, rite and music.

At that time, people disrelished the slaughter of Mac Dynasty, heaven and earth still cherished Le Dynasty. He came out to participate in the army with Clairvoyant-peaceful Great Royal Prince (Trinh Kiem), restore Le Dynasty, protect the Western area, marsch the army to Bang Tuong. Just at the beginning, the morality and loyaty of the general was wellknown, the task was favorable as if matching the Earth-coin in I Ching; there were a very strong will training and educating the soliders and the gift for fighting art getting him a good name above the army.

In Thuan Binh reign's years $(1548$ - 1556) Le Trung Tong age, he commanded troops fighting the aggressors and achieved a remarkable feat, was awarded Luong Xuyen Chief-vassal title. He had never made a mistake in troops command, was forecast to be an outstanding meritorious official; commanded troops to surround and combat castles, strict and clear discipline, attack citadels and occupy lands, destroy the enemy, clear the bush. At the time, in the process of discussing merits, awarding office and title, Hoang Dinh Ai was titled Quang Tay vassal. The lower-rank troops did not have to be taught but still were strict. Using faithfulness to encourage the army, [he] dare to rush forward in dangerous places but not fear the grueling hardness, sword enemy generals and capture flag, achieve many of incredible feats; was granted: Glorious Duke. He internally involved in discussing and arranging schemes, then externally held the command of the army to fight aggressors; in the battle at the gate of Than Phu, Dan Nhai, recorded great achievements in numerous combats. The fights on the river of Hoang Ha, Xuong Giang; overall won many battles. In the ambush on Bien river, the quisling general (Mac), Khanh, was disgraceful defeated. Totally win the fights of Giao Thuy, left Thanh Tri; marching forward to seize all enemy warboats in the battles of Van La, Phu Liet. The power like the dorab struggling in the sea. All over countryside, the heroism bloomed; the battle of Phuong Nhan, blood overflowed, which dirtied and reddened the rivers.

Of the second Chinh Tri reign's year (1559), obeying the commander, his excellency directed well-trained troops to be the vanguard on the front line. The charity of the commander-in-chef was favored, thus the citizen living in the area of Kinh Bac, Hai Duong were safe and sound. The oriflamme was raised high, the essential bases of quisling invader (Mac) in Lang Son, Thai Nguyen were absolutely broken down.

In the third Chinh Tri reign's year (1560), all over the country felt great fear of the instable situation; in the fourth 
Chinh Tri year (1561), [he] obeyed the order to receive some of ten-thousand troops coming back to defense Thanh Hoa; mainly took care of quelling the riot in the town, was awarded: Hiệp mưu Cương chính, Đồng đức Công thần, followed Patriarch Peaceful Royal Prince, commanders of every regions both the army and navy joining hands to reorganize the situation, repair castles, defend and protect the citizen peacefully overcoming every difficult day. Quelling the riot and keeping the people safe, achieving numerous feats, bestowed: Kiệt tiết Tuyên Lực công thần, Grand Upbring, Glorious Duke title, taking the responsibility of scheming for the safety of society. His army was numerous and strong as bears and tigers; every time of fighting, then majestic as thunder and lightning; pursued the quisling general (Mac) at Lo Son, defeated the Mac army in the battle of Cam Thuy - Kim Son. The position of strength harmonized with Holy principles. [he] commanded the army at $\mathrm{Co}$ Moc with a prestigious fame as a ferocious tiger, surrounded the enemy at Bon Tri that the quisling general (Mac), Tran Phu, was cut off the head; killed the cruel, burnt the enemy's food storage

On $27^{\text {th }}$ December, the Quang Hung $14^{\text {th }}$ reign's year (1591) the state military drove the remnants of defeated quisling army (Mac) right to their den, looked at our hanging flags in the region of Thach That that swords and spears overshadowed the sky; his excellency complying with the order of holding the flag to lead the army vanguard to cut off the head of the quisling invader (Mac), Khuong, on the front line, to kill the quisling general (Mac), Tan, right on the horseback.

On $6^{\text {th }}$ January the Quang Hung $15^{\text {th }}$ reign's year $(1592)$, occupied the castle of Dong Quan, captured alive the enemy general (Mac), Thuong Quoc (Nguyen Quyen) at Mac Kieu, defeated the Mac army at Lo river. On $9^{\text {th }}$ of the same month, admitted the surrendering general, Bui Van Khue, on the Gia Vien land. Built the floating bridge for the army to cross. When passing by the districts of the area of Son Nam, placated the masses and officials, captured the surrendering troops. Commanded district officials to secretly transfer the food for men and horse, swore to recover Than Chau (18). On $14^{\text {th }}$ November, directed troops to privately fight at the river of Hat, the quisling army (Mac) suffered a bitter defeat, capture a lot of boats and weapons, then marched back to the imperial city, soldiers and officials had many advantages to comfort, their families were joyful.

On $9^{\text {th }}$ January the Quy Ty $16^{\text {th }}(1593)$, drew the great army back to celebrate in Kinh $\mathrm{Su}$, captured and delivered two quisling generals (Mac), Phu and Khang an, in Dong Trieu; took back the official seal of the enemy (Mac) in the area of Yen Quang.

Universal life dust was cleared away, the light of the sun and the moon in the heaven of heavens was bright, the forbidden palace returned peace, the country was reunified. In April of the same year, his excellency welcomingly conformed the imperial carriage to the imperial city, the country was governed in peace, as if the majesticalness of a Han powerful official came to light, similar to the recovery of lands of Chu Dynasty. The wind blew gently in the ether. The world was contented. The court defined merits and rewarded, his excellency huân lao phiệt diệt was granted favors, awarded: Hữu tướng, Grand Military Mandarin, Glorious Grand Duke. As the common sense, institutionalizing the national rite before he was awarded for his merits. At that time, there was an important postal district Lang Son where adjoined the North couttry, and was the path that the envoy ambassador goes past; then, entrust him with the task of keeping Lang Son, a region with a small citadel, muôn dặt trường thành, therefore, desired for a widely-open common border and an excellent communication between two sides.

On $24^{\text {th }}$ August Earth-Pig year, the Quang Hung $22^{\text {sd }}$ reign's year (1599) The Tong emperor was in heaven, at the time, his excellency was still at the battlefield, focused his efforts on undertaking essential tasks, always kept his mind on seeing the big picture. [he] reported and referred to Grand Marshal, Primary National General, Patriarch Peaceful Royal Prince (Trinh Tung) giving the order that [he] together with Great Military Mandarin, Honorable Grand Duke (Nguyen Dien) designed a big scheme, obeyed to bring gold books, official seals throning the crown prince, change the name of reign's years to the first Thuan Duc reign's year (1600). In the first dawning, the political situation was clear and bright, all former officials were appointed to important posts. His excellency, the high-ranking elder, was highly meritorious and respected, was additionally awarded: Literature-Affair Collective Declamation, Court-Affair Participation. His excellency always desires the concord, takes on businesses with prestige, dedicates himself to common work; his righteousness and generosity was well-known, which won the hearts. His magnanimity madethe national pulse longlasting. His manner and attitude was deliberate. [he] was the representative personality at the royal palatial area, [and] was as firm as the big timber on the mountain of Thai Son. At the dawn of new reign, without using much effort, the world was flowing, happy, peaceful and prosperous.

In May the second Thuan Duc reign's year (1601) unfortunately, rebellious subjects, Phan Ngan and Ngo Dinh Nga, assembled the army violating the border, the whole country was separate. His excellency thought that he, who keeps the roots stable, must destroy the invader in person; granted Suy Trung Duc Van, Chancellor with Glorious Great Duke title, took world affairs in his own responsibility. [he] put his own ability and intellect on nurture the benefaction, discussed the work carefully assisting the king, reorganised military force, horses and elephants, raised to the east that attacked right into the den. This battle becoming famous didn't look like the former that as if gods followed, the army marched forward to win at once. It took no more than a morning that the country returned peace, the rebellious subject Dinh Nga was arrested at the seashore, the brothers Dao Nham were killed at Linh Giang, swept away the den of rebels, the border gate was peaceful again.

In the seventh Hoang Dinh reign's year (1607) escorted the envoy to pay tribute at the gate of Nam Quan. The envoy was profoundly respectful to receive the national seal, the path 
was clear, the two countries were perfectly communicative, holy principles were bright again after the restoration, the country was safe and sound, the fortune was reinforced, it was true that the good karma benefited the fortune which was eternally great thus.

Although the King raised the flag to eliminate the disorder and recover the homeland, [this] also was thanks to the devoted assistance of his excellency. He was like a star lighting up the high sea, like a jewel kept on the mainland. His excellency was born with the name of Dinh Thai (the other name was Cuong Bao), held the position of Organisation-Strategy Meritorious Official, Lieutenant Colonel, Gentle Duke title. His son is Phuc, holding Tan Tri Meritorious Official, Đặc tiến Phụ quốc Thượng tướng quân Điện tiền, Commander-General of the East Army, Right Commander-in-chief, Upright Duke title, His daughter married Hiep Muu Prestigous Meritorious Official, Commander-General of the South Army, Judgement Commander-in-chief, Duke title. His descendants is numerous, family relatives become increasingly luxuriant, and merits stand out in relief; futhermore, inherited a fortune of authority and possession, the sense of purpose is unshakeable. All of those advantages are owing to the great blessing that he left.

On $15^{\text {th }}$ of December the eighth Hoang Dinh reign's year (1607), his excellency caught a cold and then died at Kinh $\mathrm{Su}$, living to be eighty-one, granted the posthumous name: Hau Duc phủ quân.

$\mathrm{Oh}$ ! His excellency was the first-class meritorious personality, worthy expected favours from above; wellknown all over the reign, one's lifetime of original ethos of meritorious offices, at the place of both civil and military mandarin; his merits covered the whole of the world, the cause ranged all over the border areas. Goodness, why, didn't hold him up but let him gone; not only feudal intellectuals in the world but also the Thai Son mount shed tears that there was a national elder to be stolen away, it was not unable to memorize the hurt of the day that his excellency was centralized back to gods. The king was melancholy that stopped giving audience for 5 days, because his excellency had the great merits in forming the program to govern the country, ordered Vice Minister of Rites, Nghia Khue marquis, Nguyen Phong, to carry out the worship, granted 300 solders of the condolence money and 9 strong sentry soldiers.

Oh! His excellency was as pure as the sun and the moon, met the team of dragons in the clouds, devoted himself for the king, rebuilder the kingly dynasty; contributed to society, his virtue was well-known among citizens; treated feudal intellectuals well, did not rely vaingloriously on his achievements that discriminated between winning and losing, wealthy but not was touched with pity. His social status was above but his heart was below; golden dress, rode the xích ô horse but his carriage was unhurried; the merits presented clearly at the xiêm flag, the widespread fame was written in noble books; throughout the ages of thousands years, moral standards lighted up more and more. [he] was really a subject deserving the fame of meritorious officials of $\mathrm{Ha}$ and $\mathrm{Chu}$ Dynasties' era. Is it possible that there is a good personality as if in the good old days, request to record the true facts, carve on the firm stone in order to hand down eternally?

Minh words that:
Homeland of Vietnam

His faithful excellency

Han historic books

His professional merits

Grown-up and successful children

Posterity of Shogun

\author{
Sun and Moon light up \\ Cover up Vietnamese lands \\ Chu Dynasty's Flag \\ Bring fame eternally \\ Full of merits
}

Make the way in life eternally
March, the seventh Hoang Dinh reign's year (1607) Le Kinh Tong age

Ngo Tri Hoa, Ly Trai origin, Dong Thanh district passing the Water Dragon-year doctoral examination, being an academic vice-official, Dong Cac Great Academician, writes.

\section{Conclusion}

Thus, it might be defined that the epitaph has a remarkable value in term of historical materials; through the contents of the epitaph, contributes additions to historical studies, lifetime merits of the personality Thái Tể Glorious Duke Hoang Dinh Ai, also concretely historical materials about the task of quelling Mac Dynasty, restoring Le Dynasty that historical collections are still lacking. Especially from the contents ofthe name and tile of the epitaph recorded, we can redefine the writer of the epitaph, that is $\mathrm{PhD}$ Ngo Tri Hoa, who was born in Ly Trai village, Dong Thanh district, Nghe An province, a famed official under the reign of Le Trung Hung; which is a basis to assist researchers in adding notable work when studying Ngo Tri Hoa.

\section{Notes (Our Aim Is to Clarify the Content so Use "Notes" Here Is Correct)}

1. Family annals, now, is kept by Mr. Hoang Dinh Dao, is of descendants of the Hoang Dinh family, residing at Vinh Loc town, Vinh Loc district, Thanh Hoa province

2. By investigating in Van Lung village, Thach Thanh district (now Thanh Minh village, Thach Thanh district, Thanh Hoa province) where to burry and to set up the theological epitaph. The epitaph has been lost.

3. Luu Cong Dao (1816): "Vinh Loc district monograph", code VHv.1371/AB. "Vinh Loc climatic monograph" coding A.2537 "Thanh Hoa province Vinh Loc district monograph", coding VHv.137/AB (Han edition). The books was translated. Nguyen Van Hai synthetized and translated, Thanh Hoa publisher 2010, first reprinted 2012.

4. Phan Huy Chu (1960) as "Regulations of Dynasties in Classification”, History Publisher. Geography Book, Personality Book page 273. The books "Complete Annals of Dai Viet' 
5. Tu Su Buddhist monk (1982) "Literacy of Minh Biet", People literature publisher, pp. 150

6. Ngo Non (1982) "Literacy of Minh Biet", People literature publisher, pp.53, epitaph part.

7. Nowadays is Vinh Hung village, Vinh Loc district, Thanh Hoa province where Trinh Lords rised up originally

8. According to the real examinations and the genealogy recorded: Dinh Thai afterwards emigrated to Thien Vuc village, Vinh Phuc district, the native land of the quaestor Trinh Ra, the time Cao Bien lived. Nowadays, at Vuc hamlet, Vinh Ninh village, Vinh Loc district, Thanh Hoa province, still are there cành trưởng và từ đường to worship Hoang Dinh Thai

9. Thieu Khang: had the merits to recover Ha Dynasty, to end the period of "no-king 40 years", from the phase that Thai Khang lost the country. The posterities call him "restoring Thieu Khang".

10. La Cong: that La Vong, the real name is Khuong Thuong, tự is Tu Nha, so is called Khuong Tu Nha, he was a greatly talented general and contributed to the establishment of Chu Dynasty (TQ) prolonging more than 800 years.

11. Tuyen Vuong: that Chu Tuyen Vuong was the son of Chu Le Vuong, has the name of Co Tinh, rule from $827 \mathrm{BC}$ to $782 \mathrm{BC}$, the eleventh King of Chu Dynasty who had the merits in restoring Chu Dynasty.

12. Tu Di: Based on the History of Chu reigns, have fights with Hoai Di and Tay Nhung. Hoan Di even said his name Hoan Nam Di or Nam Di, originally was a tribe of southrooted Dong Di. In the age of Chu Le Vuong, Ngac marquis was in coalition with Hoai to combat against Chu Dynasty. Chu Le Vuong ordered Quac Cong Truong Phu to fight, then destroyed the country of Ngac, but Hoai Di did not submit. In 823 BC, Chu Tuyen Vuong ordered Doan Cat Phu to fight Hoai Di, declared that Hoai Di despised the emperor, pestered border areas. After that, Hoai Di refused to pay tribute, Tuyen vuong ordered Trieu Muc công commanded troops to conquer, forming a coalition with $\mathrm{Te}, \mathrm{Ki}$, Lai to defeat Hoai Di. Thus, Hoai Di had to ask for peace and pay tribute regularly.

13. 14. 15. 16: provided with notes above
17. The authentic words recorded in the family annals was mistaken into the fiftieth Thong Nguyen reign's year. In the fact of the history, Le Cung Hoang was to be a King, took only one name of reign: Thong Nguyen prolonging in 5 years from 1522 to 1527 . But the Fire-Pig year is 1527 .

18. Indicating PR China that means unifying the country as the PR China.

\section{References}

[1] Academy of Social Sciences of Vietnam (1993) "Complete Annals of Dai Viet”, Hanoi Social Sciences Publisher.

[2] Tran Thi Kim Anh- Hoang Hong Cam (2010) Han Literature Genres of Vietnam. Hanoi Social Sciences Publisher.

[3] Phan Huy Chu (1960) "Regulations of Dynasties in Classification”, History Publisher.

[4] Luu Cong Dao (1816) "Vinh Loc district monograph", code VHv.1371/AB. (Han edition).

[5] "Vinh Loc climatic monograph" A.2537. (Han edition).

[6] "Thanh Hoa province Vinh Loc district monograph", code: VHv.137/AB (Han edition).

[7] "Thanh Hoa province Vinh Loc district monograph". Translator Nguyen Van Hai, Thanh Hoa Publisher 2010, first reprinted in 2012 .

[8] Ngo Duc Tho - Chief Author (2006) Vietnamese competitionexamination laureates. Literature Publisher.

[9] Department of Study and Compile of Thanh Hoa History (2006) Thanh Hoa Celebrities. Thanh Hoa Publisher.

[10] Department of Study and Compile of Thanh Hoa History (2001) Names of Villages, volume 1, volume 2, Thanh Hoa Publisher.

[11] Provincial committee of the party - People's Council People's Committee, Thanh Hoa monograph, volume 1, volume 2, Hanoi Social Sciences Publisher.

[12] Trinh Nhu - Chief author (2010) Hoang Hoa cultural celebrities, Education Publisher - Ha Noi. 